Cover. Background photograph-Brooks Creek at Eddie Perry Road near Bynum Left inset photograph-Pigeon House Branch at Crabtree Boulevard at Raleigh Right inset photograph—Hare Snipe Creek at Secondary Road 1822 near Leesville

Photographs taken by the ALBE/NAWQA Field Team 


\section{Selected Physical, Chemical, and Biological Data for 30 Urbanizing Streams in the North Carolina Piedmont Ecoregion, 2002-2003}

By E.M. Giddings, Michelle C. Moorman, Thomas F. Cuffney, Gerard McMahon, and Douglas A. Harned

National Water-Quality Assessment Program

Data Series 279 


\section{U.S. Department of the Interior DIRK KEMPTHORNE, Secretary}

\section{U.S. Geological Survey \\ Mark D. Myers, Director}

\section{U.S. Geological Survey, Reston, Virginia: 2007}

For product and ordering information:

World Wide Web: http://www.usgs.gov/pubprod

Telephone: 1-888-ASK-USGS

For more information on the USGS — the Federal source for science about the Earth, its natural and living resources, natural hazards, and the environment:

World Wide Web: http://www.usgs.gov

Telephone: 1-888-ASK-USGS

Any use of trade, product, or firm names is for descriptive purposes only and does not imply endorsement by the U.S. Government.

Although this report is in the public domain, permission must be secured from the individual copyright owners to reproduce any copyrighted materials contained within this report.

Suggested citation:

Giddings, E.M., Moorman, M., Cuffney, T.F., McMahon, Gerard, and Harned, D.A., 2007, Selected physical, chemical, and biological data for 30 urbanizing streams in the North Carolina Piedmont ecoregion, 2002-2003: U.S. Geological Survey Data Series 279, 14 p. (online only at http://pubs.water.usgs.gov/ds279) 


\section{Foreword}

The U.S. Geological Survey (USGS) is committed to serve the Nation with accurate and timely scientific information that helps enhance and protect the overall quality of life and that facilitates effective management of water, biological, energy, and mineral resources (http://www.usgs.gov/). Information on the quality of the Nation's water resources is of critical interest to USGS because it is so integrally linked to the long-term availability of water that is clean and safe for drinking and recreation and that is suitable for industry, irrigation, and habitat for fish and wildlife. Escalating population growth and increasing demands for multiple water uses make water availability, now measured in terms of quantity and quality, even more critical to the long-term sustainability of our communities and ecosystems.

The USGS implemented the National Water-Quality Assessment (NAWQA) Program to support national, regional, and local information needs and decisions related to water-quality management and policy (http://water.usgs.gov/nawqa/). Shaped by and coordinated with ongoing efforts of other Federal, State, and local agencies, the NAWQA Program is designed to answer: What is the condition of our Nation's streams and ground water? How are the conditions changing over time? How do natural features and human activities affect the quality of streams and ground water, and where are those effects most pronounced? By combining information on water chemistry, physical characteristics, stream habitat, and aquatic life, the NAWQA Program aims to provide science-based insights for current and emerging water issues and priorities. NAWQA results can contribute to informed decisions that result in practical and effective waterresource management strategies that protect and restore water quality.

Since 1991, the NAWQA Program has implemented interdisciplinary assessments in more than 50 of the Nation's most important river basins and aquifer systems, referred to as Study Units (http://water.usgs.gov/nawqa/studyu.html). Collectively, these Study Units account for more than 60 percent of the overall water use and population served by public water supply, and are representative of the Nation's major hydrologic landscapes, priority ecological resources, and agricultural, urban, and natural sources of contamination.

Each assessment is guided by a nationally consistent study design and methods of sampling and analysis. The assessments thereby build local knowledge about water-quality issues and trends in a particular stream or aquifer while providing an understanding of how and why water quality varies regionally and nationally. The consistent, multi-scale approach helps to determine if certain types of water-quality issues are isolated or pervasive, and allows direct comparisons of how human activities and natural processes affect water quality and ecological health in the Nation's diverse geographic and environmental settings. Comprehensive assessments on pesticides, nutrients, volatile organic compounds, trace metals, and aquatic ecology are developed at the national scale through comparative analysis of the Study-Unit findings (http://water.usgs. gov/nawqa/natsyn.html).

The USGS places high value on the communication and dissemination of credible, timely, and relevant science so that the most recent and available knowledge about water resources can be applied in management and policy decisions. We hope this NAWQA publication will provide you the needed insights and information to meet your needs, and thereby foster increased awareness and involvement in the protection and restoration of our Nation's waters. 
The NAWQA Program recognizes that a national assessment by a single program cannot address all water-resource issues of interest. External coordination at all levels is critical for a fully integrated understanding of watersheds and for cost-effective management, regulation, and conservation of our Nation's water resources. The Program, therefore, depends extensively on the advice, cooperation, and information from other Federal, State, interstate, Tribal, and local agencies, nongovernment organizations, industry, academia, and other stakeholder groups. The assistance and suggestions of all are greatly appreciated.

Robert M. Hirsch Associate Director for Water 


\section{Contents}

Abstract
Introduction.
Purpose and Scope
Description of Study Area
Data Collection and Processing Methods
Streamflow Variability and Stream Temperature
$\quad$ Stream Chemistry
Semipermeable Membrane Devices
Data Processing

\section{Figures}

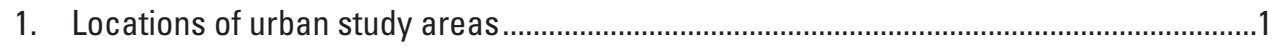

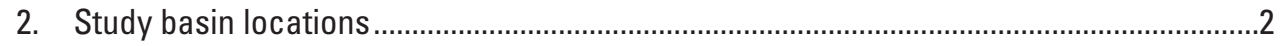

\section{Table}

1. Study basin names, identification numbers, drainage areas, and locations.....................3 
Conversion Factors

\begin{tabular}{|c|c|c|}
\hline Multiply & By & To obtain \\
\hline \multicolumn{3}{|c|}{ Length } \\
\hline centimeter $(\mathrm{cm})$ & 0.3937 & inch (in.) \\
\hline millimeter (mm) & 0.03937 & inch (in.) \\
\hline micron $(\mu \mathrm{m})$ & 0.0003937 & inch (in.) \\
\hline meter $(\mathrm{m})$ & 3.281 & foot (ft) \\
\hline kilometer $(\mathrm{km})$ & 0.6214 & mile (mi) \\
\hline \multicolumn{3}{|c|}{ Area } \\
\hline square meter $\left(\mathrm{m}^{2}\right)$ & 0.0002471 & acre \\
\hline hectare (ha) & 2.471 & acre \\
\hline square kilometer $\left(\mathrm{km}^{2}\right)$ & 247.1 & acre \\
\hline square centimeter $\left(\mathrm{cm}^{2}\right)$ & 0.001076 & square foot $\left(\mathrm{ft}^{2}\right)$ \\
\hline square meter $\left(\mathrm{m}^{2}\right)$ & 10.76 & square foot $\left(\mathrm{ft}^{2}\right)$ \\
\hline square centimeter $\left(\mathrm{cm}^{2}\right)$ & 0.1550 & square inch $\left(\mathrm{in}^{2}\right)$ \\
\hline hectare (ha) & 0.003861 & square mile $\left(\mathrm{mi}^{2}\right)$ \\
\hline square kilometer $\left(\mathrm{km}^{2}\right)$ & 0.3861 & square mile $\left(\mathrm{mi}^{2}\right)$ \\
\hline \multicolumn{3}{|c|}{ Volume } \\
\hline liter $(\mathrm{L})$ & 33.82 & ounce, fluid (fl. oz) \\
\hline liter $(\mathrm{L})$ & 2.113 & pint $(p t)$ \\
\hline liter $(\mathrm{L})$ & 1.057 & quart (qt) \\
\hline liter $(\mathrm{L})$ & 0.2642 & gallon (gal) \\
\hline cubic meter $\left(\mathrm{m}^{3}\right)$ & 264.2 & gallon (gal) \\
\hline cubic meter $\left(\mathrm{m}^{3}\right)$ & 0.0002642 & million gallons (Mgal) \\
\hline liter $(\mathrm{L})$ & 61.02 & cubic inch $\left(\mathrm{in}^{3}\right)$ \\
\hline cubic meter $\left(\mathrm{m}^{3}\right)$ & 35.31 & cubic foot $\left(\mathrm{ft}^{3}\right)$ \\
\hline cubic meter $\left(\mathrm{m}^{3}\right)$ & 1.308 & cubic yard $\left(\mathrm{yd}^{3}\right)$ \\
\hline cubic meter $\left(\mathrm{m}^{3}\right)$ & 0.0008107 & acre-foot (acre-ft) \\
\hline \multicolumn{3}{|c|}{ Flow rate } \\
\hline meter per second $(\mathrm{m} / \mathrm{s})$ & 3.281 & foot per second (ft/s) \\
\hline cubic meter per second $\left(\mathrm{m}^{3} / \mathrm{s}\right)$ & 70.07 & acre-foot per day (acre-ft/d) \\
\hline cubic meter per second $\left(\mathrm{m}^{3} / \mathrm{s}\right)$ & 35.31 & cubic foot per second $\left(\mathrm{ft}^{3} / \mathrm{s}\right)$ \\
\hline cubic meter per second $\left(\mathrm{m}^{3} / \mathrm{s}\right)$ & 22.83 & million gallons per day (Mgal/d) \\
\hline \multicolumn{3}{|c|}{ Mass } \\
\hline $\operatorname{gram}(\mathrm{g})$ & 0.03527 & ounce, avoirdupois (oz) \\
\hline
\end{tabular}

\section{SI Prefixes:}

$$
\begin{aligned}
& \text { milli }=10^{-3} \\
& \text { micro }=10^{-6} \\
& \text { nano }=10^{-9} \\
& \text { pico }=10^{-12} \\
& \text { micron }=\text { micrometer }
\end{aligned}
$$

Temperature in degrees Celsius $\left({ }^{\circ} \mathrm{C}\right)$ may be converted to degrees Fahrenheit $\left({ }^{\circ} \mathrm{F}\right)$ as follows:

$$
{ }^{\circ} \mathrm{F}=\left(1.8 \times{ }^{\circ} \mathrm{C}\right)+32
$$

Vertical coordinate information is referenced to the North American Vertical Datum of 1988 (NAVD 88).

Horizontal coordinate information is referenced to North American Datum of 1983 (NAD 83).

Altitude, as used in this report, refers to distance above the vertical datum.

Specific conductance is given in microsiemens per centimeter at 25 degrees Celsius $\left(\mu \mathrm{S} / \mathrm{cm}\right.$ at $\left.25{ }^{\circ} \mathrm{C}\right)$.

Concentrations of chemical constituents in water are given either in milligrams per liter (mg/L) or micrograms per liter $(\mu \mathrm{g} / \mathrm{L})$. 


\title{
Selected Physical, Chemical, and Biological Data for 30 Urbanizing Streams in the North Carolina Piedmont Ecoregion, 2002-2003
}

\author{
By E.M. Giddings, M. Moorman, Thomas F. Cuffney, Gerard McMahon, and Douglas A. Harned
}

\section{Abstract}

This report provides summarized physical, chemical, and biological data collected during a study of the effects of urbanization on stream ecosystems as part of the U.S. Geological Survey's National Water-Quality Assessment study. The purpose of this study was to examine differences in biological, chemical, and physical characteristics of streams across a gradient of urban intensity. Thirty sites were selected along an urbanization gradient that represents conditions in the North Carolina Piedmont ecoregion, including the cities of Raleigh, Durham, Cary, Greensboro, Winston-Salem, High Point, Asheboro, and Oxford. Data collected included streamflow variability, stream temperature, instream chemistry, instream aquatic habitat, and collections of the algal, macroinvertebrate, and fish communities. In addition, ancillary data describing land use, socioeconomic conditions, and urban infrastructure were compiled for each basin using a geographic information system analysis. All data were processed and summarized for analytical use and are presented in downloadable data tables, along with the methods of data collection and processing.

\section{Introduction}

This report provides summarized physical, chemical, and biological stream data collected at 30 stream sites along an urban gradient in central North Carolina during 2002-2003. These data were collected as part of the U.S. Geo- logical Survey's (USGS) National Water-Quality Assessment (NAWQA) Program study on the effects of urbanization on stream ecosystems (EUSE), which examines the magnitude and pattern of response in stream biological communities, hydrology, habitat, and water chemistry as basins are urbanized near 10 metropolitan areas throughout the United States (fig. 1). The presented data are from one of these metropolitan areas; namely, the Raleigh-Durham and associated metropolitan areas in North Carolina. Understanding the interrelationships of urban land use and physical, chemical, and biological stream responses may contribute to informed decisions that result in practical and effective water-resource management and strategies to protect and restore stream ecosystems.

Further information about the urban streams program can be found at http://co.water.usgs.gov/nawqa/EUSE/.

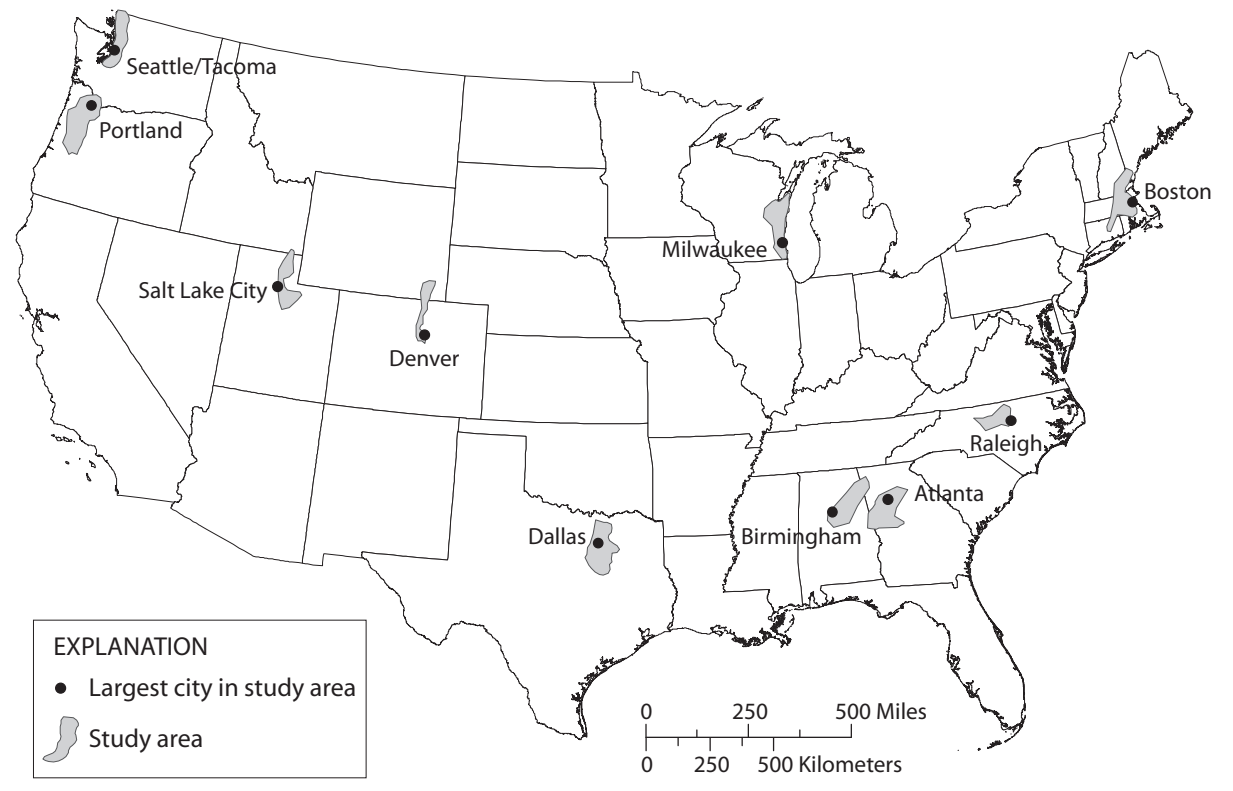

Figure 1. Locations of urban study areas. 


\section{Purpose and Scope}

This report documents data-collection and processing methods used in the North Carolina EUSE study (2002-2003) and presents summaries of the data. Data presented here have been processed and summarized in preparation for analytical use. Unprocessed (raw) data are accessible through the NAWQA data warehouse at http://water.usgs.gov/nawqa/ data. This report describes the study area, data collection and summarization methods, and provides summary data tables of hydrologic and temperature summary statistics, water chemistry, instream habitat, fish, macroinvertebrate, algal assemblages and metrics, and basin characteristics. The data tables can be downloaded as Microsoft Excel files.

\section{Description of Study Area}

The study area in North Carolina is in the southeastern United States, and includes the five metropolitan statistical areas (MSAs) of Raleigh-Cary (2000 population of 797,071); Greensboro-High Point (population of 643,430); Durham (population of 426,493); Winston-Salem (population of 421,961); and Burlington (population of 130,800) (fig. 2; U.S. Census Bureau, 2003). These five combined MSAs increased in population by 27.7 percent from 1990 to 2000 (U.S. Census Bureau, 2003).

The study area is in the Piedmont ecoregion (Omernik, 1987), specifically in three subecoregions: Northern Outer Piedmont, Southern Outer Piedmont, and Carolina Slate Belt. Landforms in the Piedmont ecoregion are irregular plains with some hills (Griffith and others, 2002). Altitude in the study area ranges from about 50 to 315 meters (m; 164 to 1,033 feet; U.S. Geological Survey, 2005a). Land use in the study area has undergone major transformations from oak-hickory-pine forest to agricultural lands to urban and suburban lands. At one time, the region was heavily farmed in cotton, tobacco, corn, and wheat, and in many areas, the silty-clay soils that are characteristic of the region were moderately to severely eroded (Trimble, 1974).

The climate is warm and humid, with a mean annual temperature of 15 degrees Celsius (59 degrees Fahrenheit) and a mean annual rainfall of 118 centimeters (46 inches; Daymet, 2005). Rainfall is evenly distributed throughout the year; slightly more rainfall occurs in July and August, and slightly less rainfall occurs during October through December. The year prior to sampling (October 2001-September 2002) was a period of low rainfall and drought conditions in the area, although normal rainfall resumed in October 2002 after sampling was initiated in September 2002. Streams in the area typically have low to moderate gradients and gravel to cobble substrates and support warm-water biological communities. Streamflow generally is highest in the winter months and lowest in late summer.

Thirty sites, which covered a range of urban conditions but had similar natural environmental conditions, were selected for study (table 1). The site basins ranged from 5 to 82 square kilometers in size and land use ranged from 3 to 98 percent urban. Sites were selected from a pool of candidate basins based on urban conditions in the basin, minimum required habitat characteristics at the site, and access and accessibility. The method of site selection was the same as that described by Tate and others (2005).

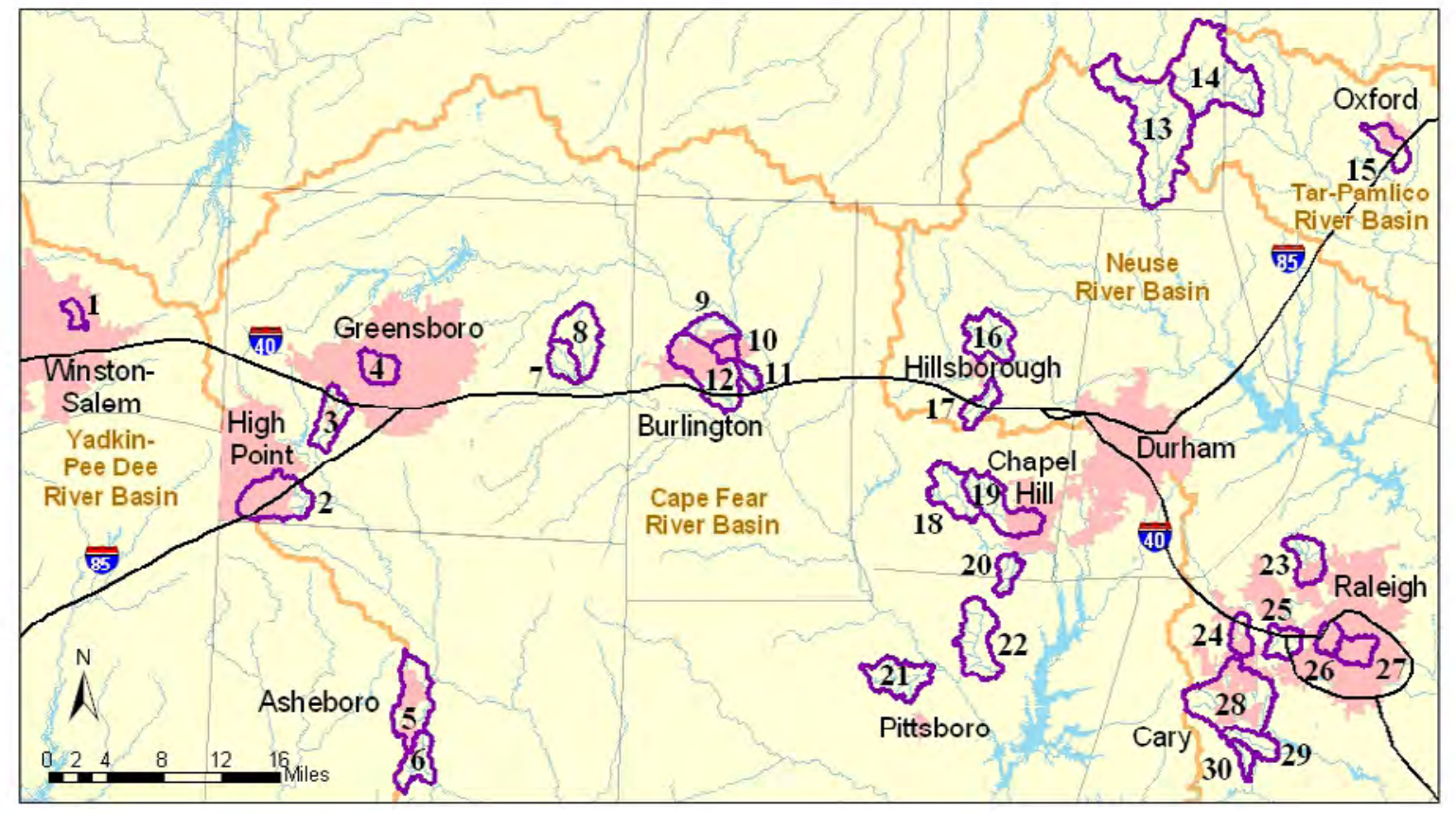

Figure 2. Study basin locations. (See table 1 for key to study basin numbers. Additional information on study basin characteristics is available at $h$ ttp://nc.water.usgs.gov/albe/General/ulug/ULUG_page.html.) 
Table 1. Study basin names, identification numbers, drainage areas, and locations.

$\left[\mathrm{km}^{2}\right.$, square kilometers; SR, secondary road]

\begin{tabular}{|c|c|c|c|c|c|}
\hline $\begin{array}{l}\text { Map no. } \\
\text { (fig. 2) }\end{array}$ & Site name & $\begin{array}{c}\text { USGS } \\
\text { station ID }\end{array}$ & $\begin{array}{l}\text { Drainage area } \\
\left(\mathbf{k m}^{2}\right)\end{array}$ & Latitude & Longitude \\
\hline 1 & Bowen Branch near mouth at Winston-Salem, NC & 0211583580 & 5.02 & 360705 & 801246 \\
\hline 2 & Richland Creek near Archdale, NC & 02099480 & 32.69 & 355628 & 795556 \\
\hline 3 & Bull Run at NC 29/70 near Jamestown, NC & 02099238 & 17.95 & 355953 & 795536 \\
\hline 4 & North Buffalo Creek at Greensboro, NC & 0209517912 & 12.38 & 360521 & 794944 \\
\hline 5 & Hasketts Creek below SR 2149 near Central Falls, NC & 02100295 & 30.43 & 354547 & 794718 \\
\hline 6 & Vestal Creek near Asheboro, NC & 02100634 & 16.45 & 353933 & 794637 \\
\hline 7 & $\begin{array}{l}\text { Rock Creek tributary at Stoney Creek Golf Course near } \\
\text { Sedalia, NC }\end{array}$ & 0209665940 & 11.66 & 360354 & 793558 \\
\hline 8 & Rock Creek above Rock Creek tributary near Whitsett, NC & 0209665990 & 25.98 & 360357 & 793558 \\
\hline 9 & Service Creek above Dry Creek at Burlington, $\mathrm{NC}$ & 0209647280 & 12.74 & 360634 & 792409 \\
\hline 10 & Dry Creek above Service Creek at Burlington, NC & 0209647295 & 6.50 & 360632 & 792412 \\
\hline 11 & Branch Creek at NC 54 near Graham, NC & 0209651815 & 4.92 & 360330 & 792242 \\
\hline 12 & Little Alamance Creek at SR 2309 near Graham, NC & 0209679804 & 37.35 & 360210 & 792437 \\
\hline 13 & Deep Creek near Moriah, NC & 02085430 & 82.49 & 361425 & 785320 \\
\hline 14 & Tar River near Berea, NC & 02081190 & 66.25 & 362003 & 784603 \\
\hline 15 & Foundry Branch at mouth near Oxford, NC & 02081510 & 12.56 & 361641 & 783522 \\
\hline 16 & Strouds Creek at St Marys Road near Hillsborough, NC & 0208501535 & 23.15 & 360515 & 790353 \\
\hline 17 & Cates Creek near Hillsborough, NC & 0208500600 & 10.88 & 360355 & 790514 \\
\hline 18 & Morgan Creek near White Cross, NC & 02097464 & 21.45 & 355525 & 790654 \\
\hline 19 & Bolin Creek above Franklin Street near Chapel Hill, NC & 02097355 & 27.07 & 355538 & 790218 \\
\hline 20 & Wilson Creek at Mouth near Chapel Hill, NC & 0209750881 & 9.17 & 355330 & 790340 \\
\hline 21 & Brooks Creek at Eddie Perry Road near Bynum, NC & 0209695780 & 23.88 & 354634 & 791004 \\
\hline 22 & Pokeberry Creek near Pittsboro, NC & 0209697900 & 29.79 & 354628 & 790713 \\
\hline 23 & Hare Snipe Creek at SR 1822 near Leesville, NC & 0208726995 & 16.01 & 355230 & 784144 \\
\hline 24 & Black Creek at Weston Parkway near Cary, NC & 0208725055 & 8.99 & 354948 & 784710 \\
\hline 25 & Richlands Creek at Schenk Forest near Cary, NC & 0208726370 & 11.24 & 355002 & 784312 \\
\hline 26 & Beaverdam Creek at Glenwood Avenue at Raleigh, NC & 0208730725 & 7.98 & 354900 & 783939 \\
\hline 27 & Pigeon House Branch at Crabtree Boulevard at Raleigh, NC & 0208732610 & 11.37 & 354825 & 783650 \\
\hline 28 & Swift Creek near Apex, NC & 02087580 & 54.39 & 354308 & 784508 \\
\hline 29 & Dutchmans Branch at SR 1386 near McCullers Crossroads, NC & 0208758440 & 11.73 & 354132 & 784407 \\
\hline 30 & Camp Branch above SR 1390 near Holly Springs, NC & 0208794025 & 5.54 & 353946 & 784611 \\
\hline
\end{tabular}

\section{Data Collection and Processing Methods}

At each study site, a wide range of data was collected from September 2002 through November 2003. Continuous stream stage and stream temperature were collected for the entire study period. Instream chemical conditions were measured synoptically 2 to 6 times, and passive samplers were deployed to detect hydrophobic organic contaminants.
Measures of instream habitat conditions and samples of the macroinvertebrate, algal, and fish communities were collected once. Basin characteristics were detailed using a geographic information system (GIS).

\section{Streamflow Variability and Stream Temperature}

Continuous stream temperature and stage were collected using a submersible pressure transducer with an internal data 
logger and temperature sensor (Greenspan Technology Pty Ltd, 2002). Standard USGS streamgaging techniques for collection of streamflow data were not used because of the short term of data collection at the sites and limited resources for the project. However, the precision of the stage measurement methods used were suitable for the study analysis. The pressure transducer had a range of zero to $30 \mathrm{~m}$ and an accuracy of plus or minus $( \pm) 0.036 \mathrm{~m}$ ( $0.12 \mathrm{foot})$. This level of accuracy does not meet the USGS standard for accuracy of stage data, which is $\pm 0.003 \mathrm{~m}$ (0.01 foot; Sauer, 2002); therefore, the unit values are not published here. A submersible pressure transducer records the pressure of water above the transducer membrane. This value is then converted to water depth from field measurements. The transducer model used in this study recorded changes in stream stage as a result of both waterlevel changes and atmospheric-pressure changes. As a result, the data were corrected for fluctuations in atmospheric pressure by using barometric pressure data from nearby airports and adjusting for differences in altitude.

Stream-stage values collected at 15-minute intervals were converted subsequently to cross-sectional area and estimated discharge values. A relation between stream stage and crosssectional area was established by surveying the cross section at the location of the transducer installation. A relation between stream stage and discharge was estimated using a combination of collected discharge measurements and a one-dimensional steady-flow hydraulic model (HEC-RAS). One to six discharge measurements were taken at each of the 30 sites during low flow. These measurements were used to establish a stage-discharge relation at low flow. At medium to high flows, standard USGS methods for establishing a stage-discharge rating curve were not used due to limited resources for collecting streamflow measurements under these conditions. Instead, the stage-discharge relation was estimated by the HEC-RAS model using measured channel slope and geometry (at 1 to 12 channel cross-sections), estimated channel roughness (Manning's N), and where appropriate, downstream surveys of constrictions, such as bridges or culverts. The model calculates flow depth and velocity using conservation of mass and energy and a boundary friction formulation for an open-channel, turbulent flow (U.S. Army Corps of Engineers, 1995; Hoggan, 1997). The full-stage estimated discharge rating curve and the stage cross-sectional area rating curve then were applied to the continuous stage data to achieve a record of continuous estimated discharge and continuous cross-sectional area values. Discharge values were compared further with records from nearby standard USGS streamgages to correct the records for obvious errors. Corrections also were applied to the crosssectional area record.

Stream stage, cross-sectional area, and estimated discharge values were summarized using hydrologic variability metrics. An hourly dataset was created using the data point collected at the beginning of each hour, and this dataset was used in further analysis to reduce necessary computing resources. Metrics were calculated to summarize overall hydrologic variability; the rate of change-of-flow levels (or flashiness); and the magnitude, frequency, and duration of high and low flows, using SAS statistical software (version 9.1 for Windows). Calculations were based on a 1-year time period, from November 16, 2002, through November 15, 2003. Missing values were not estimated, and the amount of missing data is given as a percentage for each site.

Daily mean, maximum, and minimum temperatures were computed from measurements made every 15-minutes. In addition, the daily mean and daily maximum temperature changes in a 1-hour time period were computed. Temperature accuracy for the sensor is specified by the manufacturer to be $\pm 1{ }^{\circ} \mathrm{C}$, although a test of 20 percent of the transducers used in a parallel study indicated better accuracy for temperature than the manufacturer stated (Lori Sprague, USGS Colorado Water Science Center, written commun., December 2005).

\section{Stream Chemistry}

Stream chemistry conditions were measured from samples collected at each of the 30 study sites during the spring (February 19-March 4, 2003) and summer (June 30July 16, 2003). Nine of the sites were sampled up to four additional times between October 2002 and September 2003 (Cates Creek, Black Creek, Richlands Creek at Schenk Forest, Hare Snipe Creek, Beaverdam Creek, Pigeon Creek, Camp Creek, Bolin Creek, and Morgan Creek; fig. 2). One site, Swift Creek near Apex (02087580), was sampled monthly. Water temperature, air temperature, $\mathrm{pH}$, specific conductance, and dissolved oxygen were measured in the field at the time of sampling. Water samples were collected at equal-width increments across the stream channel and processed on site in accordance with standard USGS protocols (Wilde and others, 1999; Wilde and others, 2002). Water samples were analyzed at the USGS National Water-Quality Laboratory (NWQL) in Denver, Colorado, for concentrations of chloride and sulfate (Fishman and Friedman, 1989), nutrients (Fishman, 1993), dissolved and suspended carbon (Brenton and Arnett, 1993; Zimmermann and others, 1997), and pesticides (Sandstrom and others, 2001). Samples were analyzed for suspended-sediment concentration at the USGS Kentucky Sediment Laboratory (Guy, 1969).

The NWQL has established two detection limit values-a lower method detection limit, which is set to avoid a false negative reading (not detecting a compound when it actually is present), and a higher reporting limit to avoid a false positive reading (detecting a compound when it actually is not present). If a compound is identified at a concentration between these two limits, the result is noted with an "e" to indicate that the concentration has been estimated (Childress and others, 1999). The estimated values are greater than zero but are known with less confidence than values above the reporting limit. Values also may be noted as estimated when the detected concentration is outside of the calibration range for the instrument, when the average recovery for the analyte in quality-assurance samples is less than 60 percent, or when the analyte is regu- 
larly detected in laboratory blank samples. Estimated concentrations must be interpreted with caution. Values reported with a less than symbol $(<)$ were not detected at the lower methoddetection limit, and are presented as less than the (higher) reporting limit (Childress and others, 1999).

Pesticide data were summarized using several methods. The number of detections and total concentrations of different pesticide groups, such as insecticides and herbicides, were compiled. In addition, a pesticide toxicity index (PTI) was developed. The PTI combines information on exposure of aquatic biota to pesticides with toxicity estimates for multiple pesticides in each sample and produces a relative index value for a sample or stream (Munn and others, 2006). The PTI value is computed for each sample of streamwater by summing the toxicity quotients for all pesticides detected in the sample. The toxicity quotient is the measured concentration of a pesticide in a stream sample divided by its median toxicity concentration from bioassays, such as $\mathrm{LC}_{50}$ or $\mathrm{EC}_{50}$. Separate PTI values were computed for fish, cladocerans, and benthic invertebrates in this report by using median toxicity concentrations from Munn and others (2006).

\section{Semipermeable Membrane Devices}

To examine concentrations of hydrophobic organic compounds over time, semipermeable membrane devices (SPMDs) were placed at each site for a period of approximately 6 weeks during April and May 2003. SPMDs are passive samplers that concentrate trace levels of hydrophobic organic compounds in the water column. They are designed to mimic the bioaccumulation of organic compounds in the fatty tissues of aquatic organisms. Among the organic compounds that can be sequestered by the SPMDs are polychlorinated dioxins and furans, polycyclic aromatic hydrocarbons (PAHs), polychlorinated biphenyls (PCBs), organochlorine insecticides, and pyrethroid insecticides.

At the end of the 6-week deployment period, compound residues concentrated in the SPMDs were recovered and separated from the lipid by dialysis in an organic solvent by using methods described in Huckins and others (1990). Three assays were run on the dialysates from each site - an ultraviolet (UV) fluorescence scan (Johnson and others, 2004), a Microtox ${ }^{\circledR}$ bioassay (Johnson, 1998), and a P450RGS test (Ang and others, 2000). The UV fluorescence scan provided a semiquantitative screen for PAHs, which fluoresce under UV light. SPMD extracts were exposed to UV light at 280 nanometers, and a fluorometer was used to measure the fluorescence of the extract from each site compared with a standard curve for pyrene. The resulting estimated PAH concentration for each site is reported as the equivalent number of micrograms of pyrene in 1 milliliter of SPMD extract that would produce the same fluorescence as the sample. The Microtox ${ }^{\circledR}$ bioassay measured the light production of photo-luminescent bacteria when exposed to the SPMD residues; the biochemical pathway for light production is lowered by a wide range of compounds sequestered by the SPMDs. Results are reported as the effective concentration, in milligram per milliliter, of SPMD extract that reduces light output by 50 percent (EC50), which means the lower the number, the more toxic the extract. The P450RGS test, provides a rapid screen for aryl hydrocarbon receptor (AhR) compounds that include PCBs, PAHs, dioxins, and furans. All vertebrates produce detoxifying enzymes upon exposure to AhR compounds; the amount of enzymes produced is directly proportional to the concentration of the compounds. Quantifying one of these enzymes (the gene CYP1A1) serves as a measure of dioxin activity. The concentration of AhR compounds in the SPMD extract that induces CYP1A1 production is expressed as the amount of dioxin, in toxic equivalents (TEQs), which would induce the same response. Samples for the fluoroscan test were run in duplicate, and the Microtox ${ }^{\circledR}$ and P45ORGS assays were run in triplicate. Results are reported as mean values.

A portion of each SPMD dialysate also was sent to the NWQL for identification and quantification of the target compounds (Tom Leiker, U.S. Geological Survey, written commun., 2005). Internal standards and injection internal standards were added to the dialysates just prior to gas chromatography/mass spectrometry analysis to test for quality assurance. The dialysates were analyzed by capillary gas chromatography under two different ionization conditions. Electron-capture negative ionization was used to measure compounds like pesticides, PCBs, and brominated diphenyl ethers in the SPMD extracts. Electron ionization, the conventional method for analyzing dialysates by mass spectrometry, was used to measure compounds like alkyl phenols, polycyclic musks, and plant and fecal steroids. Mass spectra for individual target compounds and retention times from sample extracts were compared with authentic standards from the standard curve for identification. A 6-point linear calibration curve was used for quantification.

Results of the toxicity tests and chemical analyses were normalized for time of exposure, because the time of exposure has a direct effect on the concentrations in the SPMD. Values were divided by time of exposure and multiplied by 45 days. Therefore, the values reported have the appropriate units described in the respected analytical methods per 45 days of exposure. This allows values for all endpoints to be comparable between all sites.

\section{Instream Habitat}

Stream physical habitat characteristics were quantified during late-summer low flows (September 2003) using standard NAWQA protocols (Fitzpatrick and others, 1998). A 150-m long reach was established at all sites except Tar River and Deep Creek (fig. 2), where a 250-m long reach was used. These lengths were at least 20 times the average stream width, a stream length that should encompass at least one full meander bend in natural stream systems (Leopold and others, 1964). The Tar River and Deep Creek are wider than the other sampled streams, so a longer reach was necessary to meet the 
minimum length. Data were collected at 11 equally spaced transects along the sampling reach. At each transect, measurements were taken of wetted and bankfull channel width, bankfull channel depth, bank morphology and conditions, and riparian canopy cover. At each transect, water velocity and depth were measured at three instream points. At these same instream points and at water's edge, observations were made of the bed substrate and presence or absence of six different types of habitat cover (macrophytes, woody debris, overhanging vegetation, boulders, manmade structures, or undercut banks). The dominant bed material at each measurement point was assigned to 1 of 10 particle-size classes, ranging from the smallest for clay and silt (class 1) to the largest for boulders greater than 500 millimeters $(\mathrm{mm})$ in average diameter (class 10). For substrates larger than $16 \mathrm{~mm}$ in diameter (large gravel), the percentage of the large particle that was embedded in sand or silt (embeddedness) was recorded. The gradient of each stream reach was recorded using a level and rod, and the length and types of geomorphic units (riffle, run, pool) in each reach were recorded.

Instream habitat measurements were summarized for each reach to include minimum, maximum, and mean values, and coefficients of variation for wetted channel width, depth, velocity, and canopy cover. Minimum, maximum, and mean values were calculated for bankfull width, bankfull depth, width-to-depth ratios, bank vegetative cover and shading, and embeddedness. Measurements taken at points were summarized for bank erosion, substrate classes, silt covering of substrate, and habitat cover types. To assess riffle and run geomorphic units, the wetted width, depth, velocity, bankfull width, bankfull depth, and width-to-depth ratios were averaged for transects within a reach marked as riffles or runs. To facilitate comparisons of habitat characteristics among sites, average bankfull width, depth, and channel area of riffle and run transects within a reach were standardized by dividing by basin drainage area.

To summarize channel characteristics in the sampling reach, several habitat metrics were calculated. Wetted cross sectional area, wetted perimeter, and channel shape were calculated at each transect and summarized for the reach using mean, minimum, and maximum values (equations 1,2 , and 3). Hydraulic conditions were summarized by calculating the mean Froude number, mean Manning's roughness, and flow stability (equations 4,5 , and 6). Hydraulic radius (mean cross sectional area / mean wetted perimeter) was calculated for each reach, and overall channel habitat was summarized from two gross measures - reach area (reach length $\times$ mean wetted channel width) and reach volume (reach length $\times$ mean width of wetted channel $\times$ mean depth).

WettedCrossArea $=($ WetWidth $*$ MeanDepth $)$

WettedPerimeter $=($ WetWidth $)+2 *($ MeanDepth $)$
ChannelShape $=(\text { WetWidth } / \text { MeanDepth })^{(\text {MeanDepth } / \text { MaxDepth })}$

Froude $=$ MeanVelocity $/ \sqrt{\text { MeanDepth } * g}$

Manning $=(\text { HydRad })^{2 / 3} *(\text { WatSurfGrad })^{1 / 2}$

FlowStab = MaxDepth $/$ BankfullDepth

where

WetWidth is the wetted width at the transect;

MeanDepth is the average depth at the transect;

MaxDepth is the maximum depth at the transect;

MeanVelocity is the average velocity at the transect;

$g$ is the gravitational acceleration constant $=$

9.807 meters per second;

HydRad is the average hydraulic radius for the reach;

WatSurfGrad is the water surface gradient for the reach; and

BankfullDepth is the depth during bankfull conditions at the transect.

\section{Biological Communities}

\section{Data Collection}

Biological data were collected from the $150-$ or $250 \mathrm{~m}$ long stream reaches established for characterizing instream habitat. Standard NAWQA sampling protocols were used to collect benthic macroinvertebrates and algae (Moulton and others, 2002) during late May to mid-June 2003. For both organism types, a quantitative sample was composed of five subsamples from riffles with cobble/gravel substrates. This sample was called the richest targeted habitat (RTH) sample because, in these streams, riffles were presumed to contain the richest assemblage of algae and macroinvertebrates. RTH macroinvertebrate subsamples consisted of Slack samples (each 0.25 square meters, 500-micron mesh net) from five separate riffle areas in the sampling reach and combined to form a single composite sample of 1.25 square meter area. RTH algal subsamples were collected by scraping the upper surface of cobbles collected from five riffle areas ( 3 to 5 cobbles from each area) in conjunction with the macroinvertebrate RTH samples. A foil template of each rock surface was collected and later digitized to determine the area sampled.

In addition, for macroinvertebrates, a qualitative multihabitat (QMH) sample was collected, which consisted of macroinvertebrates collected from as many habitats in the stream reach as were accessible. The QMH sample was collected using a 500-micron mesh dip net supplemented with hand picking of substrates. Sampling effort (measured as time) was 
apportioned as equally as possible among accessible habitats in the sampling reach. For algae, an additional quantitative sample was collected from a composite of five samples from depositional targeted habitats (DTH). DTH samples were collected by inverting a 47-mm diameter plastic petri dish and gently pressing it into the sediment surface, and then sliding a spatula under the petri dish to trap the sediment and removing the petri dish full of sediment.

Fish communities at each site were sampled during early summer low flows (mid- to late June 2003) using published protocols (Moulton and others, 2002). Two-pass electrofishing was used at each site. A backpack electrofisher was used to sample all sites except the Tar River (02081190) and Deep Creek (02085430) where a tote barge, equipped with a 2.5 generator powered pulsator (GPP) and two anode poles, was used. Fish were identified, examined for abnormalities, weighed, and measured in the field by Dr. Wayne Starnes and Gabriella Hogue of the North Carolina State Museum of Natural Science (NCSMNS). Voucher specimens and specimens that could not be definitely identified in the field were returned to the NCSMNS for processing and incorporation into the NCSMNS permanent collections.

\section{Laboratory Analysis}

Macroinvertebrate samples were preserved in 10-percent buffered formalin and sent to the USGS National Water Quality Laboratory (NWQL) in Denver, Colorado, for taxa identification and enumeration. Invertebrate samples were processed using standard NAWQA protocols (Moulton and others, 2000) for RTH samples using the randomized 300-organism count and for QMH samples using the method of fixed processing time designed to maximize the number of taxa enumerated samples.

Aliquots of the algal RTH samples were taken to assess assemblage composition and biomass as chlorophyll $a$ (Chl a) and ash-free dry mass (AFDM). For DTH samples, only assemblage data were assessed. The assemblage aliquots were preserved in 5-percent buffered formalin and sent to the Philadelphia Academy of Natural Sciences for identification and enumeration (Charles and others, 2002). The biomass aliquots were filtered on 45-micron glass-fiber filters, packed in dry ice, and sent to the NWQL for analysis.

\section{Data Processing}

Prior to analysis, biological datasets were examined for errors and corrected for taxonomic ambiguities. Taxonomic ambiguities arise when organisms from a particular sample or group of samples are not identified to the same taxonomic level. For example, an ambiguity exists in a sample if some organisms are identified to Genus (for example, Hydropsyche sp.) and some organisms are identified to species within that Genus (for example, H. sparna, H. betteni). In this case, sparna and betteni are children of the ambiguous parent Hydropsyche. The presence of taxonomic ambiguities is a problem in determining taxa richness (for example, is taxa richness in the above example 1,2 , or 3?) or when comparing the taxonomic composition of one or more samples by using techniques such as ordinations, cluster analysis, similarity indices, or diversity indices.

Ambiguities in the invertebrate and algal data were resolved using software specifically developed for use in the NAWQA Program-Invertebrate Data Analysis System (IDAS, version 3.9.5; Cuffney, 2003) and the Algal Data Analysis System (ADAS, version 2.4.5). The ADAS program is a modification of IDAS for use with algae. Ambiguities in the RTH invertebrate and algal samples, and in the DTH algal sample data were resolved by applying an option in these programs that processes samples separately by site and then distributes the abundance of an ambiguous parent among children in proportion to the relative abundance of each child. This procedure maximizes taxa richness without affecting taxa abundance.

To create a comprehensive list of taxa present at each site, a qualitative richness dataset (QQ) was created for invertebrates. This dataset consisted of a combination of all taxa found in the RTH and QMH samples. Ambiguities in the QMH and QQ samples were handled by deleting the ambiguous parents, since the taxonomic information carried by ambiguous parents already resides in the children. Fish were almost entirely identified to species level. Consequently, there was very little ambiguity in those data. A small number of individual fish were identified to a higher taxonomic level. These fish were eliminated from the analysis.

Biological metrics were calculated for fish, invertebrates, and algae. Metrics are individual variables or combinations of variables that emphasize specific data characteristics. They commonly are used in bioassessments to reduce the complex site-by-species matrix to a few variables that are thought to have significance ecologically and(or) are indicative of water-quality changes (Barbour and others, 1999). Metrics calculated from the invertebrate and algal data were based on measures of abundance, richness, functional groups (for invertebrates), biomass (for algae), tolerance, and indices of diversity. Invertebrate traits used in the calculation of metrics are from Barbour and others (1999) and Cummins (1973). Algal classifications were compiled from Lowe (1974), Bahls (1993), and Van Dam and others (1994) (Attributes file version 8, S.D. Porter, USGS Colorado Water Science Center, written commun., 2006). Metrics calculated from the fish data were based on richness, abundance, biomass, total length, tolerance, trophic guild (for example, herbivore, insectivore), and traits (for example, reproductive strategy, substrate preference). Fish tolerance classifications and trophic guilds were from the North Carolina Department of Environment and Natural Resources (2001), and trait classifications were from Goldstein and Meador (2004). 


\section{Ancillary Data}

Geographic information system (GIS) analysis was used to characterize the natural and anthropogenic basin characteristics for each site. Basin boundaries were derived from USGS 30-m national elevation data (U.S. Geological Survey, 2005a). The boundaries then were overlain with mapped data representing natural features and human activities and values. Most variables were derived based on characteristics for the entire basin; however, several categories of variables were calculated on finer scales, such as within riparian zones or stream segments. Streams were mapped from the USGS National Hydrography Dataset (NHD) at the 1:100,000 scale (U.S. Geological Survey 2005b). GIS-derived variables are presented in the broad categories of natural environmental setting (ecoregions, soils, topography, climate), land cover, landscape pattern, population and housing, infrastructure, and stream segment.

The natural setting of each basin was characterized by using U.S. Environmental Protection Agency (USEPA) level IV ecoregions (Griffith and others, 2002) and USGS hydrologic landscape regions (U.S. Geological Survey, 2003). Soil properties, such as texture and drainage, were derived from the Natural Resources Conservation Service State Soil Geographic (STATSGO) database (U.S. Department of Agriculture, 1994), and topographic characteristics, such as basin relief and mean basin slope, were derived from USGS 30-m national elevation data (U.S. Geological Survey, 2005a). Basin-level mean air temperature and precipitation statistics were derived from 1-kilometer resolution Daymet model data (Daymet, 2005), which represented 18 years (1980-97) of mean temperature and precipitation data obtained from terrain-adjusted daily climatological observations.

Land-cover data were derived from the National Land Cover 1992 (NLCD92) and 2001 (NLCD01) datasets (U.S. Geological Survey, 2005c). The NLCD01 is a 16-class, 30-m resolution dataset based primarily on Landsat-7 enhanced thematic mapper data for the period 1999-2002, which represents a composite for the approximate 2001 timeframe. In addition to the 16-class dataset, land-cover data were aggregated to eight Level I classes (for example, deciduous forest, evergreen forest, and mixed forest were aggregated to "forest;" Anderson and others, 1976). The NLCD01 also contains a subpixel percent impervious-surface data layer. An internal accuracy assessment found a general underestimation of impervious surface (mean difference from ground truth $=-13.4$ percent) using the NLCD01 data (James Falcone, USGS, written commun., February 2006). Land-cover variables were calculated for each study basin and stream riparian zone, based on NHD stream lines for the entire basin. The riparian zone was defined as the area extending approximately $100 \mathrm{~m}$ on each side of the stream centerline.

Landscape pattern metrics characterizing the shape, size, and spatial configuration of land-cover patches were derived by using the FRAGSTATS software package (McGarigal and Marks, 1995). Basin land-cover data were reclassified to Level
I classifications (water, urban, forest), and then FRAGSTATS metrics were calculated for patches of each class type. An additional metric (Basin Shape Index) was calculated based on the entire basin boundary.

Basin population and population density were calculated based on 2000 Census block-level data (GeoLytics, Inc., 2004). All other census variables (demographic, labor, income, and housing characteristics) were calculated based on 2000 Census block-group data. Four socioeconomic indexes (SEI) were additionally derived based on principal component ordination of 65 census variables, as described in McMahon and Cuffney (2000). The ordination extracts the primary sources of variability among census block groups, such that the first axis of the ordination (represented by SEI-1) describes the principal ways that the block groups can be distinguished. Subsequent axes describe the next most important ways that the data are structured. Area weighting was used to apportion values for these indices and the associated 65 variables from the block groups to each of the study basins. Variable weights for each axis are provided in the descriptive portion of the basin characterization (census) data file. Infrastructure data were based on Census 2000 TIGER roads (GeoLytics, Inc., 2004), point-source dischargers from USEPA National Pollutant Discharge Elimination System (NPDES) locations (U.S. Environmental Protection Agency, 2005a), and Toxic Release Inventory locations ( U.S. Environmental Protection Agency, 2005b).

To examine stream conditions close to the sampled reach, stream segments were identified. These segment lengths were defined as a function of drainage area $\left(\log ^{10} \times\right.$ drainage area $\times 1,000)$ and were located starting at the study site and proceeding upstream. NLCD01 land-cover statistics were derived for the riparian zone $(\sim 100 \mathrm{~m}$ each side of the stream centerline) of the stream segment. Stream-segment statistics were calculated for physical characteristics that were not related to land cover: sinuosity, gradient (based primarily on 30-m National Elevation Dataset (NED) data), mean distance to the nearest road, and density of road/stream intersections on the length of the segment. 


\section{Data Files}

Data files are available to download in Excel (version 2003) format. Each workbook contains one data sheet and, where necessary, one sheet with variable name definitions and notes. For site descriptions, see the table under "Description of Study Area" or download the site file. For descriptions of the data, see the associated method section.

\section{Site descriptions}

Sites.xls $(21 \mathrm{~KB})$

List of station name, number, latitude, longitude and drainage area.

\section{Hydrologic variability metrics}

\begin{tabular}{|l|l|}
\hline Hydro_metrics_discharge.xls $(60 \mathrm{~KB})$ & Metrics describing streamflow variability, calculated based on estimated discharge. \\
\hline Hydro_metrics_area.xls $(58 \mathrm{~KB})$ & Metrics describing streamflow variability, calculated based on cross sectional area. \\
\hline Hydro_metrics_stage.xls $(53 \mathrm{~KB})$ & Metrics describing streamflow variability, calculated based on stream stage. \\
\hline
\end{tabular}

\section{Temperature summary statistics}

\begin{tabular}{|l|l|}
\hline Temperat_mean.xls $(275 \mathrm{~KB})$ & Daily mean temperature. \\
\hline Temperat_maximum.xls $(191 \mathrm{~KB})$ & Daily maximum temperature. \\
\hline Temperat_minimum.xls $(183 \mathrm{~KB})$ & Daily minimum temperature. \\
\hline Temperat_MeanHrChange.xls $(269 \mathrm{~KB})$ & $\begin{array}{l}\text { The change in temperature was calculated for each hourly timestep, and the mean for } \\
\text { each day is presented. }\end{array}$ \\
\hline Temperat_MaxHrChange.xls $(244 \mathrm{~KB})$ & $\begin{array}{l}\text { The change in temperature was calculated for each hourly timestep, and the maximum } \\
\text { for each day is presented. }\end{array}$ \\
\hline
\end{tabular}

\section{Chemistry}

\begin{tabular}{|l|l|}
\hline Chemistry.xls (85 KB) & Variables describing instream chemical samples. \\
\hline SPMD_chemistry.xls (126 KB) & $\begin{array}{l}\text { Variables describing results of toxicity tests and chemical sampling for semi-perme- } \\
\text { able membrane devices (SPMDs). }\end{array}$ \\
\hline
\end{tabular}

\section{Instream habitat}

Instream_habitat.xls (67 KB)

Variables describing characteristics of the stream reach, channel dimensions, velocity and hydrologic conditions, substrate, bank, canopy cover and instream cover.

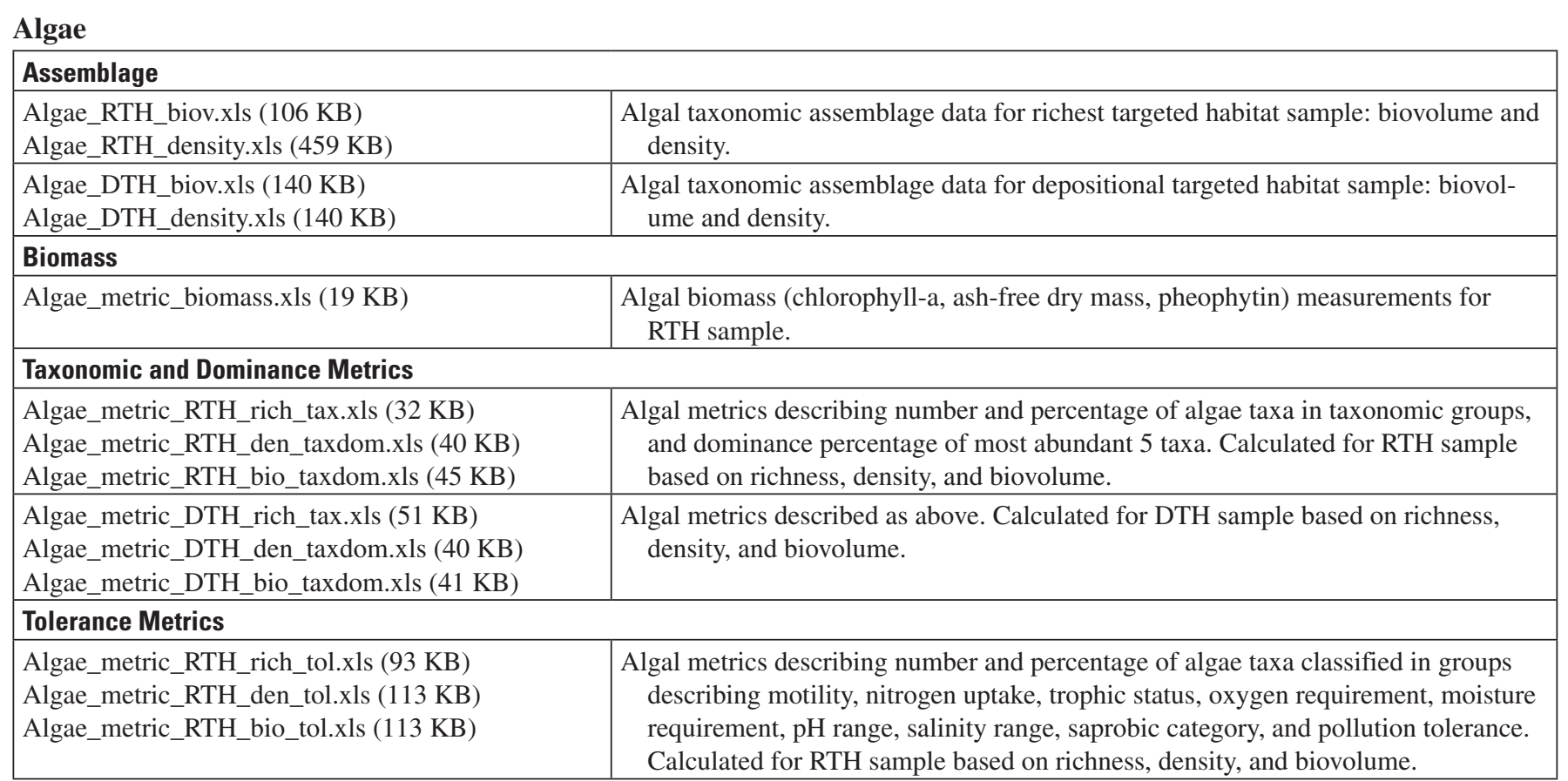


Algae_metric_DTH_rich_tol.xls (92 KB)
Algae_metric_DTH_den_tol.xls $(117 \mathrm{~KB})$
Algae_metric_DTH_bio_tol.xls $(110 \mathrm{~KB})$

Macroinvertebrate assemblages

\begin{tabular}{|c|c|}
\hline \multicolumn{2}{|l|}{ Assemblage } \\
\hline $\begin{array}{l}\text { Invert_RTH.xls ( } 72 \mathrm{~KB}) \\
\text { Invert_QMH.xls }(80 \mathrm{~KB}) \\
\text { Invert_QQ.xls }(90 \mathrm{~KB})\end{array}$ & $\begin{array}{l}\text { Macroinvertebrate assemblage data for richest targeted habitat (RTH) sample (den- } \\
\text { sity), qualitative multiple habitat (QMH) sample (presense/absence), and combined } \\
\text { list of taxa (QQ) (presense/absence). }\end{array}$ \\
\hline \multicolumn{2}{|l|}{ Metrics } \\
\hline Invert_metric_RTH.xls (94 KB) & $\begin{array}{l}\text { Macroinvertebrate metrics describing richness, percent richness, abundance, and per- } \\
\text { cent abundance of taxonomic groups, percentage of richness and abundance classi- } \\
\text { fied into functional feeding groups, tolerance classification metrics, percentage of } \\
\text { richness and abundance made up of dominant taxa and various diversity inidices. } \\
\text { Calculated for the RTH sample. }\end{array}$ \\
\hline Invert_metric_QMH.xls $(60 \mathrm{~KB})$ & $\begin{array}{l}\text { Macroinvertebrate metrics describing richness and percent richness of taxonomic } \\
\text { groups, percentage of richness classified into functional feeding groups, and toler- } \\
\text { ance classification. Calculated for the QMH sample. }\end{array}$ \\
\hline Invert_metric_QQ.xls (60 KB) & $\begin{array}{l}\text { Macroinvertebrate metrics describing richness and percent richness of taxonomic } \\
\text { groups, percentage of richness classified into functional feeding groups, and toler- } \\
\text { ance classification. Calculated for the QQ sample. }\end{array}$ \\
\hline
\end{tabular}

Fish

\begin{tabular}{|l|l|}
\hline Assemblage & \multicolumn{1}{|l|}{$\begin{array}{c}\text { Description of fish assemblage sampled including number of each species, total, aver- } \\
\text { age, standard deviation, maximum, and minimum total length and weight of each } \\
\text { species collected per site, and summary of abnormalities noted. }\end{array}$} \\
\hline Metrics & $\begin{array}{l}\text { Metrics describing total fish richness, abundance, length and weight for taxonomic } \\
\text { families of fish species. }\end{array}$ \\
\hline Fish_metrics_tax.xls (28 KB) & $\begin{array}{l}\text { Metrics describing total richness, abundance, length and weight for classifications of } \\
\text { fish tolerance and trophic guilds. }\end{array}$ \\
\hline Fish_metrics_tol.xls (34 KB) & $\begin{array}{l}\text { Metrics describing total richness, abundance, length and weight for classifications of } \\
\text { fish traits, including substrate preference, geomorphology preference, locomotion } \\
\text { habit, and reproduction technique. }\end{array}$ \\
\hline
\end{tabular}

\section{Ancillary data}

\begin{tabular}{|l|l|}
\hline Basin_envset.xls (170 KB) & $\begin{array}{c}\text { Variables used to describe basin topographic, soil, litho-chemical, ecoregion, hydro- } \\
\text { logic landscape, and climatic (temperature and precipitation) conditions. }\end{array}$ \\
\hline Basin_nlcd92.xls (39 KB) & $\begin{array}{c}\text { Variables used to describe land cover from approximately 1992. Description of basin } \\
\text { area classified into Level 1 and Level 2 land cover categories from NLCD classifi- } \\
\text { cation of 1992. }\end{array}$ \\
\hline Basin_nlcd01.xls (58 KB) & $\begin{array}{c}\text { Variables used to describe land cover from approximately 2001. Description of basin } \\
\text { area classified into Level 1 and Level 2 land cover categories, total stream buffer } \\
\text { area classified into Level 1 land cover categories, segment stream buffer area clas- } \\
\text { sified into Level 2 land cover categories, and impervious surface in basin area and } \\
\text { total stream buffer. From NLCD classification of 2001. }\end{array}$ \\
\hline Basin_fragstats.xls (79 KB) & $\begin{array}{c}\text { Variables used to describe patterns of land cover on the landscape. Describes size, } \\
\text { shape, configuration, proximity, and various indicies on patches of land classified } \\
\text { into different land use categories. }\end{array}$ \\
\hline Basin_census.xls (82 KB) & $\begin{array}{l}\text { Variables used to describe population, housing, and socioeconomic conditions in } \\
\text { study basins. }\end{array}$ \\
\hline Basin_InfSeg.xls (31 KB) & $\begin{array}{l}\text { Variables used to describe road and infrastructure characteristics of basins, and char- } \\
\text { acteristics of stream segments. }\end{array}$ \\
\hline
\end{tabular}

density, and biovolume. 


\section{Acknowledgments}

The collection and compilation of data presented in this report would not have been possible without the assistance of a dedicated team. The authors wish to thank all the members of the Albemarle-Pamlico NAWQA team, especially Jason Fine, Erik Staub, Eric Sadorf, Kristen Beckert, M. Thure Caire, Allison Haigler, and Heidi Neunkirchner, whose careful attention to detail contributed to the high quality of data collected for study. Many other people assisted with the compilation of data and methods, including Bernie Lenz and Jeff Steuer of the USGS Wisconsin Water Science Center for assistance with hydrologic modeling; Robin Brightbill of the USGS Pennsylvania Water Science Center for assistance with temperature data; James Falcone of the NAWQA Ecological Leadership Team and Silvia Terziotti and Kirsten Tighe, of the USGS North Carolina Water Science Center for GIS data support; and Lori Sprague of the USGS Colorado Water Science Center and Wade Bryant of the USGS Georgia Water Science Center for assistance with chemical data summarization. Mary Giorgino of the USGS North Carolina Water Science Center and Jason May of the USGS California Water Science Center provided suggestions that substantially improved the quality of the manuscript. Web formatting and support were provided by Ramona Traynor of the USGS North Carolina Water Science Center.

\section{References}

Anderson, J.R., Hardy, E.E., Roach, J.T., and Witmer, R.E., 1976, A land use and land cover classification system for use with remote sensor data: U.S. Geological Survey Professional Paper 964, 41 p. (accessed August 2007 at http://pubs.er.usgs.gov/usgspubs/pp/pp964).

Ang, C.Y., Inouye, L.S., McCant, D.D., and McFarland, V.A., 2000, Protocols for a rapid clean-up/extraction procedure and an improved P450RGS dioxin screening assay for sediments: Vicksburg, MS, U.S. Army Corps of Engineers Research and Development Center, DOER Technical Notes Collection (ERDC TN-DOER-C10) (accessed March 2003 at http://el.erdc.usace.army.mil/elpubs/pdf/doerc10.pdf).

Bahls, L.L., 1993, Periphyton bioassessment methods for Montana streams (rev. January 1993): Helena, MT, Department of Health and Environmental Sciences, Water Quality Bureau, 38 p. + app.

Barbour, M.T., Gerritsen, J., Snyder, B.D., and Stribling, J.B., 1999, Rapid bioassessment protocols for use in streams and wadeable rivers-Periphyton, benthic macroinvertebrates, and fish ( $2 \mathrm{~d}$ ed.): Washington D.C., U.S. Environmental Protection Agency, Office of Water (accessed March 2003 at http://www.epa.gov/owow/monitoring/rbp/).
Brenton, R.W., and Arnett, T.L., 1993, Methods of analysis by the U.S. Geological Survey National Water Quality Laboratory-Determination of dissolved organic carbon by UVpromoted persulfate oxidation and infrared spectrometry: U.S. Geological Survey Open-File Report 92-480, 12 p. (accessed August 2007 at http://pubs.er.usgs.gov/usgspubs/ ofr/ofr92480).

Charles, D.F., Knowles, C., and Davies, R.S., eds., 2002, Protocols for the analysis of algal samples collected as part of the U.S. Geological Survey National Water-Quality Assessment Program: The Academy of Natural Sciences Report 02-06, Philadelphia, PA, 124 p. (accessed March 2003 at http://water.usgs.gov/nawqa/protocols/algprotocol/index. html).

Childress, C.J.O., Foreman, W.T., Connor, B.F., and Malone, T.J., 1999, New reporting procedures based on long-term method detection levels and some considerations for interpretations of water-quality data provided by the U.S. Geological Survey National Water Quality Laboratory: U.S. Geological Survey Open-File Report 99-193 (accessed March 2003 at http://water.usgs.gov/owq/OFR_99-193/).

Cuffney, T.F., 2003, User manual for the National WaterQuality Assessment Program Invertebrate Data Analysis System (IDAS) software: version 3.0: U.S. Geological Survey Open-File Report 03-172, 103 p. (accessed August 2007 at http://pubs.water.usgs.gov/ofro3-172/).

Cummins, K.W., 1973, Trophic relations of aquatic insects: Annual Review of Entomology, v. 18, p. 183-206.

Daymet, 2005, Daymet model: Numerical Terradynamic Simulation Group, University of Montana (accessed December 2005 at http://www.daymet.org).

Fishman, M.J., ed., 1993, Methods of analysis by the U.S. Geological Survey National Water Quality Laboratory-Determination of inorganic and organic constituents in water and fluvial sediments: U.S. Geological Survey Open-File Report 93-125, 217 p. (accessed August 2007 at http://pubs.er.usgs.gov/usgspubs/ofr/ofr93125).

Fishman, M.J., and Friedman, L.C., 1989, Methods for determination of inorganic substances in water and fluvial sediments: U.S. Geological Survey Techniques of Water-Resources Investigations, book 5, chap. A1, 545 p. (accessed August 2007 at http://pubs.usgs.gov/twri/ twri5-a1/).

Fitzpatrick, F.A., Waite, I.R., D’Arconte, P.J., Meador, M.R., Maupin, M.A., and Gurtz, M.E., 1998, Revised methods for characterizing stream habitat in the National Water-Quality Assessment program: U.S. Geological Survey WaterResources Investigations Report 98-4052, 67 p. (accessed March 2003 at http://water.usgs.gov/nawqa/protocols/ WRI98-4052/index.html). 
GeoLytics, Inc., 2004, Census DVD research package, Disk 3 (1990 Long Form in 2000 boundaries; NCDB; 2000 Long Form): New Brunswick, NJ (accessed January 2005 at http://www.GeoLytics.com).

Goldstein, R.M., and Meador, M.R., 2004, Comparisons of fish species traits from small streams to large rivers: Transactions of the American Fisheries Society v. 133, p. 971-983.

Greenspan Technology Pty Ltd, 2002, Smart sensor user manual (7th ed.) (accessed December 2005 at http://www. stevenswater.com/catalog/products/water_quality_sensors/ manual/Smart2-manual.pdf).

Griffith, G.E., Omernik, J.M., Comstock, J.A., Schafale, M.P., McNab, W.H., Lenat, D.R., MacPherson, T.G., Glover, J.B., and Shelburne, V.B., 2002, Ecoregions of North Carolina and South Carolina: Reston, VA, U.S. Geological Survey, map scale 1:1,500,000, poster.

Guy, H.P., 1969, Laboratory theory and methods for sediment analysis: U.S. Geological Survey Techniques of WaterResources Investigations, book 5, chap. C1, 58 p. (accessed August 2007 at http://pubs.usgs.gov/twri/twri5cl/).

Hoggan, D.H., 1997, Floodplain hydrology and hydraulics: New York, McGraw-Hill.

Huckins, J.N., Manuweera, G.K., Petty, J.D., Mackay, Donald, and Lebo, J.A., 1993, Lipid-containing semipermeable membrane devices for monitoring organic contaminants in water: Environmental Science and Technology, v. 27, p. 2489-2496.

Huckins, J.N., Tubergen, M.W., and Manuweera, G.K., 1990, Semipermeable membrane devices containing model lipid - A new approach to monitoring the availability of lipophilic contaminants and estimating their bioconcentration potential: Chemosphere, v. 20, p. 533-552.

Johnson B.T., 1998, Microtox toxicity test system-New developments and application, in Wells, P.G., Lee, K., and Blaise, C., eds., Microscale testing in aquatic toxicology: Advances, techniques and practice: Boca Raton, FL, CRC Lewis Publishers, p. 201-218.

Johnson, B.T., Petty, J.D., Huckins, J.N., Lee, Ken, and Gauthier, Joanne, 2004, Hazard assessment of a simulated oil spill on intertidal areas of the St. Lawrence River with SPMD-TOX: Environmental Toxicology, v. 19, p. 329-335.

Leopold, L.B., Wolman, M.G., and Miller, J.P., 1964, Fluvial processes in geomorphology: New York, Dover Publications Inc., 522 p.

Lowe, R.L., 1974, Environmental requirements and pollution tolerance of freshwater diatoms: Cincinnati, OH, U.S. Environmental Protection Agency, Office of Research and Development, EPA-670/4-74-005, 334 p.
McGarigal, K., and Marks, B.J., 1995, FRAGSTATS-Spatial pattern analysis program for quantifying landscape structure: U.S. Department of Agriculture, Forest Service, Pacific Northwest Research Station, General Technical Report PNW-GTR-351, 122 p.

McMahon, Gerard, and Cuffney, T.F., 2000, Quantifying urban intensity in drainage basins for assessing stream ecological conditions: Journal of the American Water Resources Association v. 36, no. 6, p. 1247-1261.

Moulton, S.R., II, Carter, J.L., Grotheer, S.A., Cuffney, T.F., and Short, T.M., 2000, Methods for analysis by the U.S. Geological Survey National Water Quality LaboratoryProcessing, taxonomy, and quality control of benthic macroinvertebrate samples: U.S. Geological Survey Open-File Report 00-212, 49 p. (accessed March 2003 at http://nwql. usgs.gov/Public/pubs/OFRO0-212.html).

Moulton, S.R., II, Kennen, J.G., Goldstein, R.M., and Hambrook, J.A., 2002, Revised protocols for sampling algal, invertebrate, and fish communities as part of the National Water-Quality Assessment Program: U.S. Geological Survey Open-File Report 02-150 (accessed March 2003 at http://water.usgs.gov/nawqa/protocols/OFR02-150/index. html).

Munn, M.D., Gilliom, R.J., Moran, P.W., and Nowell, L.H., 2006, Pesticide toxicity index for freshwater aquatic organisms (2d ed.): U.S. Geological Survey Scientific Investigations Report 2006-5148 (accessed April 2007 at http://pubs. water.usgs.gov/sir2006-5148/).

North Carolina Department of Environment and Natural Resources, 2001, Standard operating procedure, biological monitoring - Stream fish community assessment and fish tissue: Raleigh, NC, Division of Water Quality, Environmental Services Branch, 33 p. (accessed March 2003 at http://h2o.enr.state.nc.us/esb/BAU.html).

Omernik, J.M., 1987, Ecoregions of the conterminous United States, Annals: Association of American Geographers, v. 77 , no. 1 , p. 118-125.

Sandstrom, M.W., Stroppel, M.E., Foreman, W.T., and Schroeder, M.P., 2001, Methods of analysis by the U.S. Geological Survey National Water Quality Laboratory-Determination of moderate-use pesticides and selected degradates in water by C-18 solid-phase extraction and gas chromatography/mass spectrometry: U.S. Geological Survey WaterResources Investigations Report 01-4098, 70 p. (accessed August 2007 at http://pubs.water.usgs.gov/wri01-4098/).

Sauer, V.B., 2002, Standards for the analysis and processing of surface water data and information using electronic methods: U.S. Geological Survey Water-Resources Investigations Report 01-4044, 91 p. (accessed August 2007 at http://pubs.er.usgs.gov/usgspubs/wri/wri014044). 
Tate, C.M., Cuffney, T.F., McMahon, Gerard, Giddings, E.M.P., Coles, J.F., and Zappia, Humbert, 2005, Use of an urban intensity index to assess urban effects on streams in three contrasting environmental settings, in Brown, L.R., Gray, R.H., Hughes, R.M., and Meador, M.R., eds., Effects of urbanization on stream ecosystems: Bethesda, MD, American Fisheries Society, Symposium 47, p. 291-316.

Trimble, S.W., 1974, Man-induced soil erosion on the southern Piedmont, 1700-1970: Ankeny, IA , Soil Conservation Society of America, 188 p.

U.S. Army Corps of Engineers, 1995, HEC-RAS users manual: Davis, CA, Hydrologic Engineering Center.

U.S. Census Bureau, 2003, Population in metropolitan and micropolitan statistical areas in alphabetical order and numerical and percent change for the United States and Puerto Rico-1990 and 2000 (accessed July 2006 at http://www.census.gov/population/cen2000/phc-t29/ tab01a.pdf).

U.S. Department of Agriculture, 1994, U.S. general soil map (STATSGO): Natural Resources Conservation Service Miscellaneous Publications 1492 (accessed July 2002 at http://www.ncgc.nrcs.usda.gov/products/datasets/statsgo/.)

U.S. Environmental Protection Agency, 2005a, National Pollutant Discharge Elimination System (NPDES) (accessed December 2005 at http://cfpub.epa.gov/npdes/).

U.S. Environmental Protection Agency, 2005b, Toxic Release Inventory (TRI) Program (accessed December 2005 at http://www.epa.gov/tri/).

U.S. Geological Survey, 2003, Hydrologic landscape regions of the United States: U.S. Geological Survey Open-File Report 03-145 (accessed August 2007 at http://pubs. er.usgs.gov/usgspubs/ofr/ofr03145).
U.S. Geological Survey, 2005a, National Elevation Dataset (NED) (accessed December 2005 at http://ned.usgs.gov/).

U.S. Geological Survey, 2005b, National Hydrography Dataset (NHD) (accessed December 2005 at http://nhd.usgs.gov/).

U.S. Geological Survey, 2005c, National Land Cover Database 2001 (NLCD01) (accessed December 2005 at $h t t p: / / w w w$. mrlc.gov/mrlc2k_nlcd.asp).

Van Dam, H., Mertens, A., and Sinkeldam, J., 1994, A coded checklist and ecological indicator values of freshwater diatoms from the Netherlands: Netherlands Journal of Aquatic Ecology, v. 28, p. 117-133.

Wilde, F.D., Radtke, D.B., Gibs, Jacob, and Iwatsubo, R.T., eds., 1999, Collection of water samples: U.S. Geological Survey Techniques of Water-Resources Investigations, book 9, chap. A4 (accessed October 2002 at http://pubs. water.usgs.gov/twri9A4/).

Wilde, F.D., Radtke, D.B., Gibs, Jacob, and Iwatsubo, R.T., eds., 2002, Processing of water samples (ver. 2.1): U.S. Geological Survey Techniques of Water-Resources Investigations, book 9, chap. A5 (accessed October 2002 at http://pubs.water.usgs.gov/twri9A5/).

Zimmermann, C.F., Keefe, C.W., and Bashe, J., 1997, Method 440.0-Determination of carbon and nitrogen in sediments and particulates of estuarine/coastal waters using elemental analysis: U.S. Environmental Protection Agency, Office of Research and Development (accessed June 2006 at http://www.epa.gov/nerlcwww/m440_o.pdf). 



\section{Prepared by:}

USGS Enterprise Publishing Network

Raleigh Publishing Service Center

3916 Sunset Ridge Road

Raleigh, NC 27607

For additional information regarding this publication, contact: Chief, ALBE/NAWQA Program

U.S. Geological Survey

3916 Sunset Ridge Road

Raleigh, NC 27607

phone: 1-919-571-4024

email: daharned@usgs.gov

Or visit the Albemarle-Pamlico NAWOA Project website at: http://nc.water.usgs.gov/projects/9BI33/ 
